Article

\title{
Estimation of the Mutagenic Potential of 8-Oxog in Nuclear Extracts of Mouse Cells Using the "Framed Mirror" Method
}

\author{
Leonid V. Gening *, Alexandr A. Volodin, Konstantin Y. Kazachenko, Irina V. Makarova \\ and Vyacheslav Z. Tarantul $\mathbb{D}$
}

Institute of Molecular Genetics, Kurchatov Sq. 2, Moscow 123182, Russia; volodin@img.ras.ru (A.A.V.); konstantinkazach@yandex.ru (K.Y.K.); ivmakarova@img.ras.ru (I.V.M.); tarantul@img.ras.ru (V.Z.T.)

* Correspondence: geni@img.ras.ru

Received: 11 November 2019; Accepted: 31 December 2019; Published: 3 January 2020

\begin{abstract}
We propose an improved earlier described "mirror" method for detecting in cell nuclear extracts mutations that arise in DNA during its replication due to the misincorporation of deoxyadenosine-5'-monophosphate (dAMP) opposite 7,8-dihydro-8-oxoguanine (8-oxoG). This method is based on the synthesis of a complementary chain ("mirror") by nuclear extracts of different mice organs on a template containing 8-oxoG and dideoxycytidine residue (ddC) at the $3^{\prime}$-end. The "mirror" was amplified by PCR using primers part of which was non-complementary to the template. It allowed obtaining the "framed mirror" products. The misincorporation of dAMP in "framed mirror" products forms an EcoRI restriction site. The restriction analysis of double-stranded "framed mirror" products allows a quantification of the mutation frequency in nuclear extracts. The data obtained show that the mutagenic potential of 8-oxoG markedly varied in different organs of adult mice and embryos.
\end{abstract}

Keywords: DNA lesions; 7,8-dihydro-8-oxoguanine (8-oxoG); mutagenic activity; method of detection; cell nuclear extracts; mice organs and embryos

\section{Introduction}

One of the main causes of GC-AT transversion somatic mutations is a DNA lesion, 8-oxoguanine (8-oxoG) arising in the genome under the action of reactive oxygen species (ROS) generated in cells in the processes of oxidative phosphorylation [1,2]. The intensity of the conversion of this DNA lesion into a mutation is a key moment of aging and oncological, neurological, and some other diseases [3,4]. The presence of 8-oxoG is dangerous for the stability of the genome because all known DNA polymerases insert, with different frequencies, a correct $\mathrm{dC}$ or an incorrect $\mathrm{dA}$ opposite this lesion. For replicative DNA polymerases, the insertion of $\mathrm{dA}$ is close to $100 \%$ [5]. These data show that mutations owing to 8-oxoG arise in the process of DNA replication, mostly due to the appearance of mutant dA residues in the nascent DNA, instead of correct dC [6].

In mammalian cells, there is a base excision repair (BER) pathways that reduce the mutational burden of ROS, ensuring the correct and efficient repair of A: 8-oxo G mispairs and the removal of 8-oxoG lesions from the genome [3]. In 8-oxoG:dA mispairs, $\mathrm{dA}$ is removed by MutYH glycosylase and DNA polymerase lambda for post-replicative repair $[7,8]$.

The mutagenic potential of 8-oxoG was studied over decades by various authors using different experimental systems. As early as 1991, Shibutani et al. [5] showed that the ratio of incorporated dA to $\mathrm{dC}$ opposite 8-oxoG varied for different DNA polymerases. These authors conducted the reaction of primer extension by purified DNA polymerases on an artificial template containing 8-oxoG. The 
copies obtained were separated by electrophoresis in denaturing polyacrylamide gel. It allowed to separate DNA molecules with a definite mutation from those lacking this mutation, whereas DNA with other mutations that may appear in the experiment was absent. Although the advantages of this method were obvious, it was not used or improved over the last 28 years. The reason for this was probably that the separation of equal-sized DNA molecules that differed only in one nucleotide is technically complicated.

In later experiments, a technically less complicated approach was used, whereby a primer extension assay with four parallel DNA polymerase reactions was carried out simultaneously (each of them with only one of four dNTPs) was usually performed to ascertain which nucleotide is incorporated opposite a certain lesion [9-11]. However, in all these experiments, the primer extension reaction products were not separated by electrophoresis, and therefore no conclusion could be drawn concerning the question if these lesions cause the misincorporation of only one type of nucleotides and don't generate other mutations as well.

The most advanced is the method where, at first, a specific DNA polymerase is used to obtain a copy of the template containing a DNA lesion. The obtained copy is then sequenced and studied for mutations [12]. This method allows for identifying nucleotides incorporated in the copy opposite this or that DNA lesion, and to determine if there are closely located other mutations.

Recently we proposed a "mirror" method to study the mutagenic potential of 8-oxoG using purified DNA polymerases [1]. At the first stage of this method, similar to the method used by Targgart et al. [12], a specific DNA polymerase is used to obtain a copy of the template that we called "mirror". The "mirror" method differs in that, instead of sequencing "mirror", the nucleotide opposite the lesion is identified by simple restriction analysis, whereas other mutations can be identified by the Single strand conformation polymorphism (SSCP) method. The "mirror" method allows for the analyses of much more material in a short time without additional sequencing.

However, studies with purified DNA polymerases give only a partial idea of the real situation in vivo. A more detailed information about the mutagenic potential of 8-oxoG in normal cells and in various pathologies can be obtained from using cell extracts containing the whole set of DNA polymerases and regulatory proteins. Such an approach facilitated determining the role in the correction of DNA synthesis of not only DNA polymerases, but also other proteins involved in DNA replication. For example, experiments using model DNA template, purified DNA polymerases and extracts of knocked down cells showed that accessory replication protein A and PCNA function as molecular switches that activated the efficient incorporation of correct $\mathrm{dC}$ opposite 8-oxoG of the template by DNA polymerase lambda, but blocked the incorporation of incorrect (mutant) dA [13].

Thus, on the one hand, certain DNA polymerases can, with a high probability, incorporate mutant $\mathrm{dA}$ opposite 8-oxoG in the template, and on the other hand, certain regulatory proteins inhibit this and support the trend to incorporate correct dC. However, in contrast to purified DNA polymerases, nuclear and cell extracts of mammalian cells contain not only the full set of enzymes involved in DNA synthesis and repair, but also many nucleases. These nucleases partially destroy DNA and thereby form its shorter fragments. As a result, the synthesized DNA fragments have different lengths, and only part of them can correspond to the full-size copy of the template ("mirror"). All of this complicates the use of the "mirror" method with cell extracts.

In the present work, we modified the "mirror" method and called it the "framed mirror" method. This new method allows to overcome the existing experimental difficulties and to determine the mutagenic potential of 8-oxoG in nuclear extracts of different mouse cell organs. The results obtained show that the bypass of DNA lesions caused by 8-oxoG is different in different organs of adult animals and in embryos. 


\section{Materials and Methods}

\subsection{Mice and Embryos}

The animals were treated in accordance with the European Society Council 86/609/EEC Requirement concerning the use of animals for experimental studies. The extracts of mouse organs were obtained from C57B1 strain mice (about 3 months of age). Mouse embryos were isolated on day $12-16$ of the fetal development.

\subsection{Preparation of Nuclear Extracts}

Cell nuclear extracts were prepared according to a slightly modified method described by Schreiber et al. [14]. All procedures were conducted at $0{ }^{\circ} \mathrm{C}$. Typically, $300 \mathrm{mg}$ of a mouse organ was transferred into an Eppendorf tube filled with an equal volume of $20 \mathrm{mM}$ Tris-HCl buffer, pH 7.5, with $1 \mathrm{mM}$ EDTA, $1 \mathrm{mM}$ phenylmethylsulfonylfluoride (PMSF), and $1 \mathrm{mM}$ DTT. The content of the tube was then homogenized with a Teflon pestle for $5 \mathrm{~min}$. The homogenate was then centrifuged for $5 \mathrm{~min}$ at $14,000 \mathrm{rpm}$ in an Eppendorf centrifuge. The pellet was resuspended in an equal volume of $20 \mathrm{mM}$ Tris- $\mathrm{HCl} \mathrm{pH}$ 7.5, $60 \mathrm{mM} \mathrm{KCl,} 1 \mathrm{mM}$ EDTA, $1 \mathrm{mM}$ PMSF and $1 \mathrm{mM}$ DTT. Then it was homogenized for $5 \mathrm{~min}$ with a Teflon pestle and centrifuged for $5 \mathrm{~min}$ at 14,000 rpm. The pellet was resuspended in an equal volume of $20 \mathrm{mM}$ Tris- $\mathrm{HCl} \mathrm{pH} 7.5$, with $450 \mathrm{mM} \mathrm{NaCl}, 1.5 \mathrm{mM} \mathrm{MgCl} 2,0.2 \mathrm{mM}$ EDTA, $1 \mathrm{mM}$ PMSF, and 25\% glycerol, and homogenized one more time. The homogenate obtained was incubated for $15 \mathrm{~min}$ at $0{ }^{\circ} \mathrm{C}$ with stirring, and then centrifuged as described above. The last stage was repeated twice. Two fractions obtained by extraction in buffer with high salt concentration $(450 \mathrm{mM}$ $\mathrm{NaCl}$ ) were poured together and dialyzed for $5 \mathrm{~h}$ against $300 \mathrm{~mL}$ Tris- $\mathrm{HCl}$ buffer $\mathrm{pH} 7.5,100 \mathrm{mM} \mathrm{KCl}$, $0.2 \mathrm{mM}$ EDTA, $0.5 \mathrm{mM}$ DTT and $0.1 \mathrm{mM}$ PMSF. Aliquots of the dialysate were stored at $-70^{\circ} \mathrm{C}$. Protein concentration in the fractions (10-15 mg/mL) was measured by the Bradford method [15].

\subsection{Templates and Primers for "Framed Mirror" Product Synthesis}

For the work, we used oligonucleotides synthesized by the firm "DNA synthesis" and "Eurogene", Moscow.

Templates:

AXT/ddC (with 8-oxoG $(X)$ and dideoxycytidine (ddC)):

5'-GGGATCCTGCTGCCATAGGAAXTCTTGATTGGAAAGTCGACCTGddC-3' . 45(T) (with dT in the underlined EcoRI restriction site):

5'-GGGATCCTGCTGCCATAGGAATTCTTGATTGGAAAGTCGACCTGC-3' .

$45(\mathrm{G})$ (with $\mathrm{dG}$ instead of $\mathrm{T}$ in the EcoRI restriction site):

5'-GGGATCCTGCTGCCATAGGAAGTCTTGATTGGAAAGTCGACCTGC-3' .

45(A) (with dA instead of $\mathrm{T}$ in the EcoRI restriction site):

5'-GGGATCCTGCTGCCATAGGAAATCTTGATTGGAAAGTCGACCTGC-3' .

45(C) (with dC instead of $\mathrm{T}$ in the EcoRI restriction site):

5'-GGGATCCTGCTGCCATAGGAACTCTTGATTGGAAAGTCGACCTGC-3' .

Primers:

P1: 5'-GTTGACCTACCCACACCATCCgcaggtcgactttccaatcaa-3' .

(lower case for non-complementary to template part)

P1t: 5'-CY3-GTTGACCTACCCACACCATCC-3'.

P2: 5'-CATAATTACGAGCAATATGAAgggatcctgctgccataggaa-3'.

(lower case for non-complementary to template part)

P2t: 5' -CATAATTACGAGCAATATGAA-3'. All the oligonucleotides were purified by electrophoresis in polyacrylamide gel. 


\subsection{Synthesis of the "Framed Mirror" Products}

A general scheme of the "framed mirror" synthesis method is shown in Figure 1.

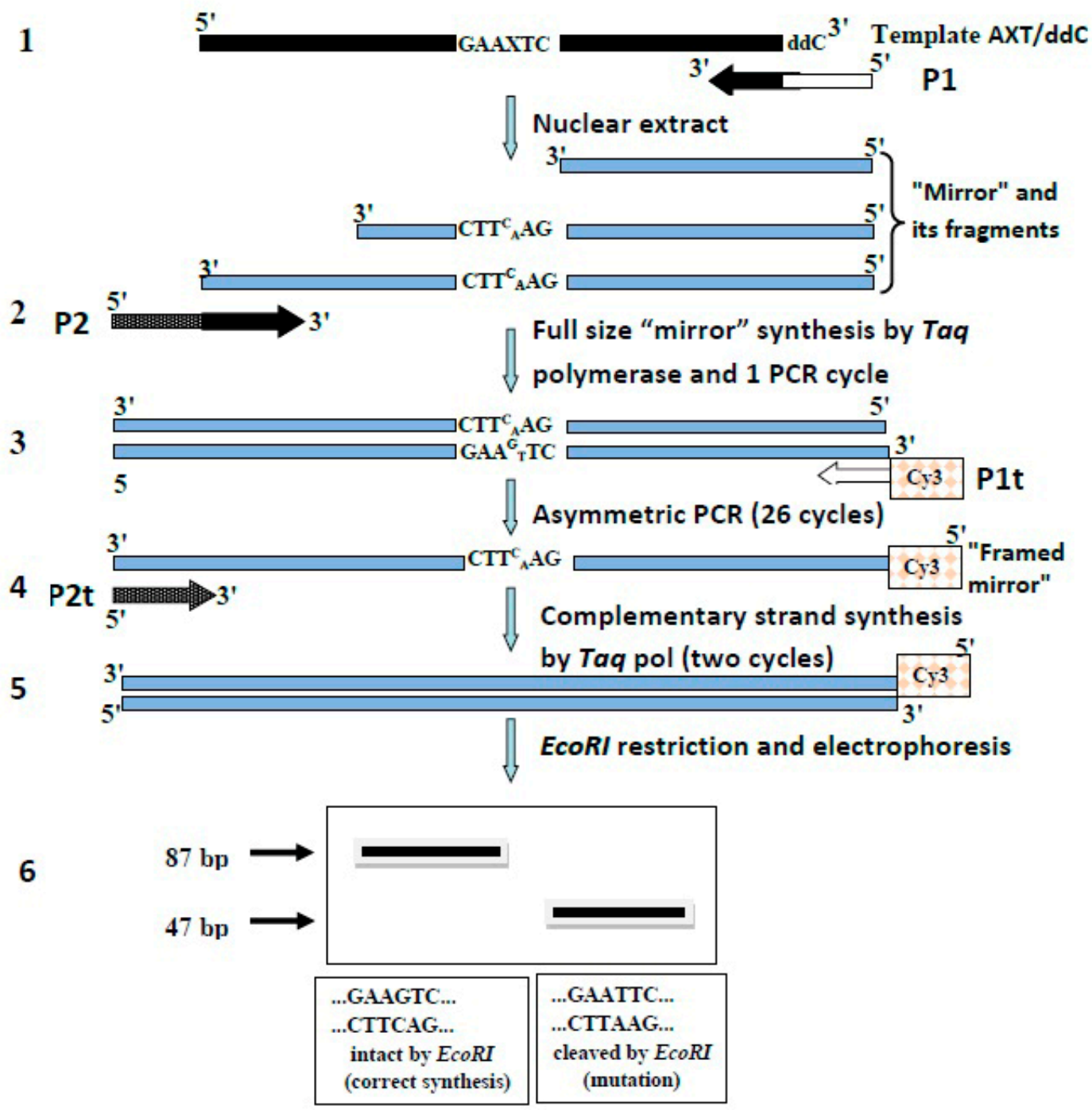

Figure 1. Scheme of the "framed mirror" method.

The synthesis of the "mirror" by cell extracts on the AXT/ddC template was done in a $30 \mu \mathrm{L}$ reaction mixture containing $50 \mathrm{mM}$ Tris- $\mathrm{HCl} \mathrm{pH}$ 8.0, $50 \mathrm{mM} \mathrm{KCl}, 5 \mathrm{mM} \mathrm{MgCl} 2,1 \mathrm{mM}$ EDTA, $1 \mathrm{mM}$ PMSF, $1 \mathrm{mM}$ DTT, $50 \mu \mathrm{g} / \mathrm{mL}$ tRNA, $0.25 \mathrm{mM}$ each of four dNTPs, $400 \mathrm{nM}$ AXT/ddC template, $400 \mathrm{nM}$ $\mathrm{P} 1$ primer, and $100 \mu \mathrm{g}$ protein of nuclear extract. The reaction mixture was incubated for $30 \mathrm{~min}$ at $37^{\circ} \mathrm{C}$. The reaction was terminated by adding EDTA up to a concentration of $10 \mathrm{mM}$. The mixture was then diluted 100 times with reaction buffer. $10 \mu \mathrm{L}$ of the diluted mixture was supplemented with $2 \times$ DreamTaq Master Mix (Thermo Scientific, Waltham, MA, USA) containing Taq polymerase and dNTP, $400 \mathrm{nM}$ primer P2 having homology with the $3^{\prime}$-end of the "mirror". Full size mirror synthesis by Taq polymerase and $1 \mathrm{PCR}$ cycle with Taq polymerase $\left(95^{\circ} \mathrm{C}, 20 \mathrm{~s} ; 95^{\circ} \mathrm{C}, 20 \mathrm{~s} ; 55^{\circ} \mathrm{C}, 20 \mathrm{~s} ; 72{ }^{\circ} \mathrm{C}, 20 \mathrm{~s} ; 72{ }^{\circ} \mathrm{C}\right.$, $5 \mathrm{~min}$ ) yielded a DNA chain complementary to the "mirror" (single-stranded "framed mirror"). At the next stage, this "framed mirror" was amplified. To this end, asymmetric PCR was carried out in the mixture with an overall volume of $50 \mu \mathrm{L}$ containing $5 \mu \mathrm{L}$ of the mixture with the single-stranded "framed mirror", $500 \mathrm{nM}$ primer P1t labeled withCY3, $5 \mathrm{nM}$ primer P2t, and $25 \mu \mathrm{L} 2 \times$ DreamTaq Master Mix (Thermo Scientific, Toronto, ON, Canada) under the following conditions: $95^{\circ} \mathrm{C}$ for $20 \mathrm{~s}$; 25 cycles of $95^{\circ} \mathrm{C}$ for $20 \mathrm{~s}$, then $60{ }^{\circ} \mathrm{C}$ for $20 \mathrm{~s}$, then $72{ }^{\circ} \mathrm{C}$ for $20 \mathrm{~s}$; and $72{ }^{\circ} \mathrm{C}$ for $5 \mathrm{~min}$. After this, the 
second strand of the "framed mirror" was synthesized in $50 \mu \mathrm{L}$ of the reaction mixture containing $20 \mu \mathrm{L}$ of the asymmetric PCR product, $25 \mu \mathrm{L}$ of $2 \times$ DreamTaq Master Mix (Thermo Scientific, Toronto, ON, Canada), and $500 \mathrm{nM}$ primer P2t. The PCR reaction was performed as follows: $95^{\circ} \mathrm{C}$ for $20 \mathrm{~s}$; 2 cycles of $95^{\circ} \mathrm{C}$ for $20 \mathrm{~s}$, then $55^{\circ} \mathrm{C}$ for $20 \mathrm{~s}$, then $72{ }^{\circ} \mathrm{C}$ for $20 \mathrm{~s} ; 72{ }^{\circ} \mathrm{C}$ for $5 \mathrm{~min}$. At the last stage, the obtained double-stranded "framed mirror" was cut with EcoRI at $37^{\circ} \mathrm{C}$ for $2 \mathrm{~h}$ in the mixture containing $10 \mu \mathrm{L}$ of the double-stranded "framed mirror", $2 \mu \mathrm{L}$ of $10 \times E c o R I$ buffer (Thermo Scientific, Toronto, ON, Canada), and $5 \mathrm{U}$ of EcoRI (Thermo Scientific, Toronto, ON, Canada).

\subsection{Electrophoretic Analysis of EcoRI Digestion Products}

The products of the EcoRI digestion were analyzed by electrophoresis in $20 \%$ polyacrylamide gel with Tris-borate buffer $\mathrm{pH} 7.5$, using 12-cm-long glass, at $18 \mathrm{~mA}$ current. The electrophoresis ran at $10{ }^{\circ} \mathrm{C}$ for $4 \mathrm{~h}$ in the dark. The resulting gel was scanned with a Typhoon FLA 9500, and the data were processed with ImageQuant ${ }^{\mathrm{TM}} \mathrm{v} 5.2$ software.

\subsection{SSCP Analysis of the Single-Stranded "Framed Mirror"}

Single-stranded products of asymmetric PCR were electrophoresed in $20 \%$ polyacrylamide gel with Tris-borate buffer, $\mathrm{pH} 7.5$, using 25-cm-long glass, at $9 \mathrm{~mA}$ current. The electrophoresis ran for $35 \mathrm{~h}$ at $10^{\circ} \mathrm{C}$ in the dark. The resulting gel was scanned with a Typhoon FLA 9500, the data were processed with ImageQuant ${ }^{\mathrm{TM}} \mathrm{v} 5.2$ software and statistically treated using Origin 8.1 program.

\section{Results}

\subsection{The "Framed Mirror" Method}

Earlier, we proposed a "mirror' method for studying the mutagenic activity of purified DNA polymerases [1]. In the present work, to estimate the mutagenic activity of 8-oxoG in nuclear extracts, we modified a "mirror" method and called it "framed mirror" method. A modification was necessary because DNA-synthesizing activity in cell extracts is rather low. Besides, apart from DNA polymerases, cell extracts contain many other enzymes (nucleases, phosphatases, DNA glycosylases etc.) which can affect the structure of the DNA template under study. The extracts can also contain components able to affect PCR. Taking all this into account, we changed the "mirror" method as shown in Figure 1.

At stage 1, a "mirror" is synthesized with primer P1 (see Section 2) on an artificial template containing 8-oxoG in its middle and dideoxycytidine (ddC) at its $3^{\prime}$-end. Primer P1 consisted of two parts. Its $3^{\prime}$-end was complementary to the template and at this end DNA synthesis started. The remaining part was homologous to primer P1t (see Section 2) and served for further amplification of the "mirror" with Taq polymerase, irrespective of the template. The ddC located at the 3 '-end of the template blocked the PCR synthesis of extra "mirrors".

At stage 2, the full size "mirror" was synthetized with a site complementary to primer P1t (Figure 1) and was performed one PCR cycle with P2 primer to obtain the "framed mirror". Simultaneously, the "framed mirror" was converted into the double-stranded form with added sites homologous to primers $\mathrm{P} 1 \mathrm{t}$ and P2t for further amplification of the "framed mirror" irrespective of the template. One cycle of PCR with Taq polymerase yielded a double-stranded copy of the "framed mirror" (double-stranded "framed mirror") that could be amplified by PCR with primers Pt1 and Pt2 (Figure 1) non-homologous to the initial template.

1. synthesis of the "mirror" on a template containing 8-oxoG.

2. Elongation of the "mirror" to obtain full-size "framed mirror" and its conversion into the double-stranded form.

3. asymmetric PCR of the double-stranded "framed mirror".

4. filling in products of the asymmetric PCR to obtain double-stranded forms.

5. restriction digestion of the double-stranded DNA fragments with EcoRI. 
6. electrophoretic analysis of the DNA fragments digested by EcoRI in polyacrylamide gel.

Elongation in the "mirror" fragments was necessary because cell extracts could not always form full-size copies of the template. Still, the size of most fragments formed in cell nuclear extracts showed that lesions of the template were mainly bypassed, and their filling in with Taq polymerase allowed to identify the nucleotide incorporated in the extracts opposite 8-oxoG.

At stage 3, asymmetric PCR with the double-stranded "framed mirror" and P1t primer was performed. This primer was not homologous to the template, and it was the only primer with a Cy3 label at its $5^{\prime}$-end. This PCR yielded Cy3-labeled single-stranded DNA fragments representing copies of the double-stranded "framed mirror". The reaction did not form copies of the template itself due to the absence of a site homologous to P1t primer and the presence of the ddC-block at the $3^{\prime}$-end of the template. Additionally, we checked the presence of other mutations that could arise under the action of cell extracts (except the incorporation dA opposite 8-oxoG) using the SSCP method.

At stage 4, to measure the mutagenic potential in extracts more accurately, the single-stranded fragments were filled in with Taq polymerase and P2t primer to create double-stranded forms (Figure 1).

At stage 5, double-strand "framed mirror" was treated with EcoRI to reveal the mutation in the replication over the lesion.

At stage 6, the products of the EcoRI treatment were analyzed in non-denaturing polyacrylamide gel.

\subsection{Study of the Mutagenic Potential of 8-Oxog in Organs of Adult Mice and Their Embryos}

The developed by us "framed mirror" method was used in the present work to determine the frequency of incorporation in the growing DNA chain of the incorrect $\mathrm{dA}$ or correct $\mathrm{dC}$ opposite 8-oxoG by nuclear extracts of different mouse organs. The initial template was designed so that the incorporation of correct dC opposite 8-oxoG would give a $87 \mathrm{bp}$ PCR product lacking EcoRI sites. On the contrary, the incorporation of incorrect $\mathrm{dA}$ at the same position should give a PCR product that could be split with EcoRI into two fragments, 40 and $47 \mathrm{bp}$ long. However, since the PCR product was labeled with Cy3 at one end, only $47 \mathrm{bp}$ long fragment was visible on the electrophoregram. Figure 2 represents an example of electrophoretic separation of double-strand products synthesized in nuclear extracts of five different mouse organs and treated with EcoRI.

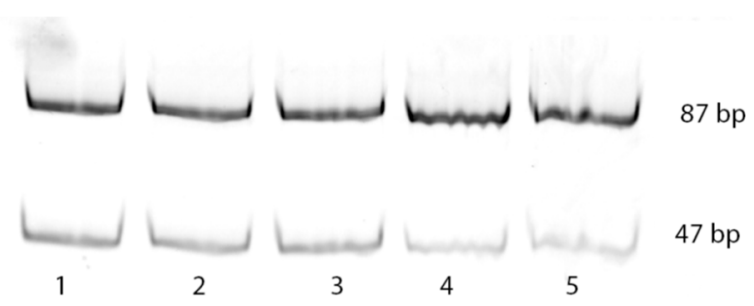

Figure 2. Electrophoregram of the double-stranded products obtained in the extracts of cell nuclei and digested with EcoRI: 1-testis, 2-liver, 3-brain, 4-kidney, 5-breast. The percent of $47 \mathrm{bp}$ band was taken as the mutagenic potential of 8 -oxoG.

As seen in Figure 2, treatment with EcoRI gave in all cases two DNA fragments: a $87 \mathrm{bp}$ long fragment due to the incorporation of correct $\mathrm{dC}$, and $47 \mathrm{bp}$ long fragment resulting from the incorporation of mutant $\mathrm{dA}$. Numeric values of the mutagenic potential for each extract were derived from the band intensities.

Figure 3 shows averaged values of the 8-oxoG mutagenic potential in different mouse organs. One can see that this potential in nuclei of testes and the brain (16-18\%) is higher than in kidneys, liver and mammary gland (8-13\%). Similar experiments with cell nuclear extracts of mouse embryos showed that the mutagenic potential in these extracts was markedly $(-25 \%)$ higher than in organs of adult mice. Also, it was roughly the same for embryos of different age (12-16 days). 


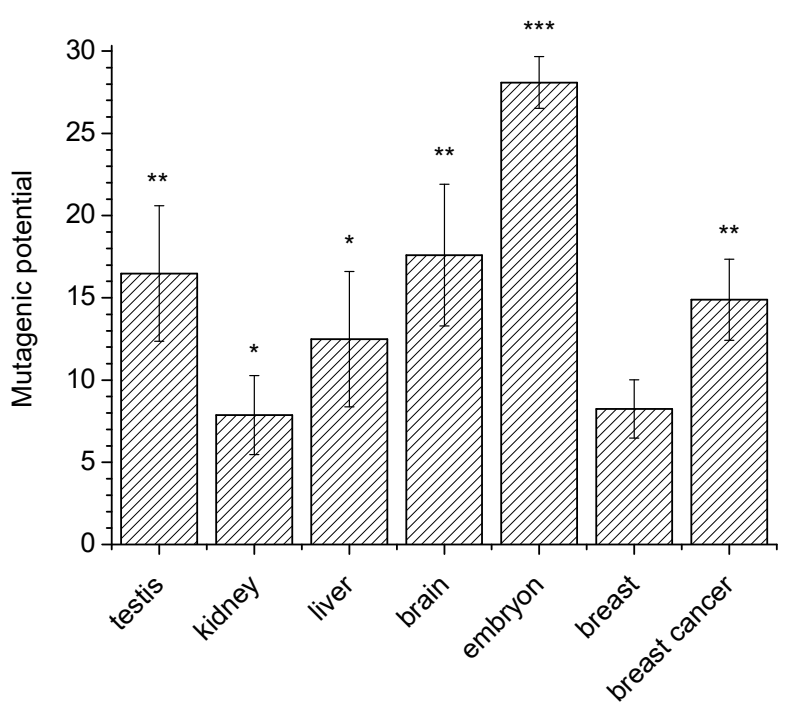

Figure 3. Values of the 8-oxoG mutagenic potential (percentage of the incorporated mutant dA relative to all incorporated nucleotides) measured by the "framed mirror" method in nuclear extracts of various mouse tissues and embryos. $p$ Values relative to breast were: * statistically insignificant; ${ }^{* *} p<0.02$; *** $p<0.001$ (averaged from at least three experiments).

The proposed method can be successfully used not to obtain absolute values, but to compare the mutagenic potential of 8-oxoG in different types of cells. For example, the mutagenic activity of 8-oxoG in the extracts of nuclei of breast cancer cells is significantly higher compared to extracts of the nuclei of normal breast cells (Figure 3).

\subsection{SSCP Analysis of the Single-Strand "Framed Mirror"}

The "framed mirror" method developed by us allows to not only determine the frequency of dA incorporation opposite 8-oxoG in cell nuclear extracts, but also to test for the presence or absence in mammalian cells of factors capable of generating other mutations during translesion synthesis. Their presence should change the banding pattern of the electrophoresed single-strand "framed mirror" obtained by asymmetric PCR at stage 3 of the method. Figure 4 exemplifies such an electrophoresis of samples obtained in analysis of different mouse organs.

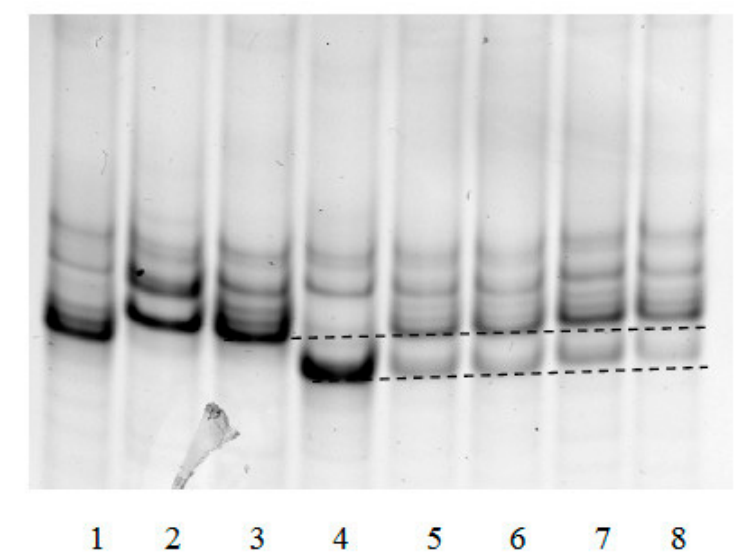

Figure 4. Separation in non-denaturing polyacrylamide gel of the products synthesized by Taq polymerase on control templates (1-4) (see Section 2), and in nuclear extracts of different organs on the template containing 8-oxoG (AXT/ddC) (5-8). Templates: 1-45T, 2-45G, 3-45C, 4-45A; organs: 5-the brain, 6-testes, 7-liver, and 8-breast. 
It can be seen that patterns of bands 5-8 correspond to only the patterns of Taq polymerase synthesis on control templates $45^{\circ} \mathrm{C}$ and $45 \mathrm{~A}$. Extra bands due to possible deletions or insertions were not observed. This, together with a detailed analysis of band intensities, showed that the only type of mutation that could be generated by 8-oxoG within the genome was the incorporation of incorrect $\mathrm{dA}$ opposite this lesion.

\section{Discussion}

There are some reports that DNA replication is not only coordinated with cell proliferation but is also regulated uniquely in some cell types and organs. The differential regulation of DNA synthesis requires an association between DNA replication and differentiation [16]. These data about association suggest that sets of enzymes involved in the DNA synthesis during differentiation and proliferation are different in different cell types. Therefore, the mutagenic potential of different DNA lesions may depend on the cell type and developmental stage of an organism. However, this type of studies is practically absent. Also, there are no data for the frequency of mutant $\mathrm{dA}$ incorporation opposite 8-oxoG instead of correct dC in mammalian cells.

In the present work, we used a new ("framed mirror") method to study the mutagenic potential of 8-oxoG lesion in different organs of mouse embryos and adult mice. To this end, we used cell nuclei extracts instead of purified enzymes. We believed that such a system was closer to the situation in vivo. The informativeness and efficiency of this system was demonstrated in a number of experiments. For example, earlier we used cell homogenates to reveal alterations in the DNA synthesis and repair during the development of loach Misgurnus fossilis [17]. Analysis of sea urchin embryo extracts [17] allowed the authors to reveal the temporal heterogeneity of DNA repair processes in animal development.

The data obtained in the present work showed that the mutagenic potential of 8-oxoG was different in mouse embryos and organs of adult mice. It is widely accepted that mutation frequency is significantly associated with proliferative activity. A relatively high mutagenic potential in nuclear extracts of embryos can be therefore explained by the intense proliferation in embryonic development. In organs of adult mice, the mutagenic potential was the highest in extracts of the brain and testes. The high potential in cell nuclear extracts of testes might be also explained by intense proliferation of cells and the presence of active replicative DNA polymerases that often incorporate dA opposite 8-oxoG within a "mirror" template. However, the relatively high incorporation of incorrect dA in cell extracts of the brain poorly agrees with the accepted view that cells of the brain practically do not proliferate and contain quantitatively prevalent DNA polymerase beta that bypasses 8-oxoG lesion relatively correctly $[18,19]$.

It can be suggested that DNA polymerase activity in the brain differs from that in other organs. In particular, we showed that, in contrast to most other organs, in extracts of mouse brain cells t-stop after incorrectly inserted dT could be overpassed by DNA polymerase iota [20].

Another interesting result of this work is a higher mutagenic potential of 8-oxoG in mouse embryos compared to organs of adult animals. This suggests that mutagenic activity of DNA lesions is changed during ontogenesis. This finding well corresponds to our earlier data. Also, analysis of incorrect activity of error-prone DNA polymerase iota in M. musculus ontogeny demonstrated considerable changes in its activity, which was the highest during the prenatal development of most organs and decreased in the adult body [21].

Using our proposed method, we also showed that the mutagenic activity of 8-oxoG in breast tumor cells is significantly higher than in normal breast cells. This fact is compatible with the well-known concept of a high level of mutagenesis in cancer cells.

Author Contributions: Investigation, A.A.V., I.V.M. and K.Y.K.; writing-review and editing, L.V.G. and V.Z.T. All authors have read and agreed to the published version of the manuscript.

Funding: This research was funded by the Russian Foundation for Basic Research (grants 16-04-00475 and 18-04-00733) and Russian Academy of Sciences (grant Molecular and Cellular Biology). 
Acknowledgments: This study was performed using equipment of the Center of Cellular and Genetic Technologies of the Institute of Molecular Genetics, Russian Academy of Sciences. We thank Boris Glotov for critically reading and providing feedback on the manuscript.

Conflicts of Interest: The authors declare no conflicts of interest.

\title{
Abbreviations and Notations
}

\author{
8-oxoG 7,8-dihydro-8-oxoguanine \\ AXT single-stranded DNA template containing 8-oxoG \\ ATT single-stranded DNA template containing $\mathrm{T}$ in place of 8-oxoG \\ AGT single-stranded DNA template containing $\mathrm{G}$ in place of 8-oxoG \\ BER base excision repair \\ dAMP deoxyadenosine-5'-monophosphate \\ ddC dideoxycytidine \\ DP direct primer \\ PMSF phenylmethylsulfonylfluoride \\ $\mathrm{RP} \quad$ reverse primer \\ ROS reactive oxygen species \\ SSCP single-strand conformational polymorphism
}

\section{References}

1. Gening, L.V.; Shevchenko, O.V.; Kazachenko, K.Y.; Tarantul, V.Z. “Mirror" method to estimate mutagenic activity of DNA lesions. Methods Protoc. 2018, 1, 32. [CrossRef] [PubMed]

2. Lindahl, T. Instability and decay of the primary structure of DNA. Nature 1993, 362, 709-715. [CrossRef] [PubMed]

3. Van Loon, B.; Markkanen, E.; Huebsher, U. Oxygen as a friend and enemy: How to combat the mutational potential of 8-oxo-guanine. DNA Repair 2010, 9, 604-616. [CrossRef] [PubMed]

4. Freudenthal, B.D.; Beard, W.A.; Perera, L.; Shock, D.D.; Kim, T.; Schlick, T.; Wilson, S.H. Uncovering the polymerase-induced cytotoxicity of an oxidized nucleotide. Nature 2015, 517, 635-639. [CrossRef] [PubMed]

5. Shibutani, S.; Takeshita, M.; Grollman, A.P. Insertion of specific bases during DNA synthesis past the oxidation-damaged base 8-oxo-G. Nature 1991, 349, 431. [CrossRef]

6. Michaels, M.L.; Miller, J.H. The GO system protects organisms from the mutagenic effect of the spontaneous lesion 8-hydroxyguanine (7,8-dihydro-8-oxoguanine). J. Bacteriol. 1992, 174, 6321-6325. [CrossRef]

7. Van Loon, B.; Hübscher, U. An 8-oxo-guanine repair pathway coordinated by MUTYH glycosylase and DNA polymerase lambda. Proc. Natl. Acad. Sci. USA 2009, 106, 18201-18206. [CrossRef]

8. Burak, M.J.; Guja, K.E.; Hambardjieva, E.; Derkunt, B.; Garcia-Diaz, M. A fidelity mechanism in DNA polymerase lambda promotes error-free bypass of 8-oxo-dG. EMBO J. 2016, 15, 2045-2059. [CrossRef]

9. Kirouac, K.N.; Ling, H. Unique active site promotes error-free replication opposite an 8-oxo-guanine lesion by human DNA polymerase iota. Proc. Natl. Acad. Sci. USA 2011, 108, 3210-3215. [CrossRef]

10. Fischhaber, P.L.; Gerlach, V.L.; Feaver, W.J.; Hatahet, Z.; Wallace, S.S.; Friedberg, E.C. Human DNA polymerase $\kappa$ bypasses and extends beyond thymine glycols during translesion synthesis in vitro, preferentially incorporating correct nucleotides. J. Biol. Chem. 2002, 277, 37604-37611. [CrossRef]

11. Crespan, E.; Hübscher, U.; Maga, G. Error-free bypass of 2-hydroxyadenine by human DNA polymerase $\lambda$ with proliferating cell nuclear antigen and replication protein A in different sequence contexts. Nucleic Acids Res. 2007, 35, 5173-5181. [CrossRef] [PubMed]

12. Taggart, D.J.; Camerlengo, T.L.; Harrison, J.K.; Sherrer, S.M.; Kshetry, A.K.; Taylor, J.S.; Huang, K.; Suo, Z. A high-throughput and quantitative method to assess the mutagenic potential of translesion DNA synthesis. Nucleic Acids Res. 2013, 41, e96. [CrossRef] [PubMed]

13. Markkanen, E.; Castrec, B.; Villani, G.; Huebsher, U. A switch between DNA polymerases $\delta$ and $\lambda$ promotes error-free bypass of 8-oxo-G lesions. Proc. Natl. Acad. Sci. USA 2012, 109, 20401-20406. [CrossRef] [PubMed]

14. Schreiber, E.; Matthias, P.; Müller, M.M.; Schaffner, W. Rapid detection of octamer binding proteins with "mini-extracts", prepared from a small number of cells. Nucleic Acids Res. 1989, 17, 6419. [CrossRef] [PubMed] 
15. Bradford, M.M. A rapid and sensitive method for the quantitation of microgram quantities of protein utilizing the principle of protein-dye binding. Anal. Biochem. 1976, 72, 248-254. [CrossRef]

16. Nordman, J.; Orr-Weaver, T.L. Regulation of DNA replication during development. Development 2012, 139, 455-464. [CrossRef]

17. Torgasheva, N.A.; Menzorova, N.I.; Sibirtsev, Y.T.; Rasskazov, V.A.; Zharkov, D.O.; Nevinsky, G.A. Base excision DNA repair in the embryonic development of the sea urchin, Strongylocentrotus intermedius. Mol. BioSyst. 2016, 12, 2247-2256. [CrossRef]

18. Kalam, M.A.; Haraguchi, K.; Chandani, S.; Loechler, E.L.; Moriya, M.; Greenberg, M.M.; Basu, A.K. Genetic effects of oxidative DNA damages: Comparative mutagenesis of the imidazole ring-opened formamidopyrimidines (Fapy lesions) and 8-oxo-purines in simian kidney cells. Nucleic Acids Res. 2006, 34, 2305-2315. [CrossRef]

19. Rao, K.S.; Annapurna, V.V.; Raji, N.S. DNA polymerase-beta may be the main player for defective DNA repair in aging rat neurons. Ann. N. Y. Acad. Sci. 2001, 928, 113-120. [CrossRef]

20. Gening, L.V.; Makarova, A.V.; Malashenko, A.M.; Tarantul, V.Z. A false note of DNA polymerase iota in the choir of genome caretakers in mammals. Biochemistry 2006, 71, 155-159.

21. Makarova, A.V.; Gening, L.V.; Makarova, I.V.; Tarantul, V.Z. Activity of error-prone DNA polymerase iota in different periods of house mouse Mus musculus ontogeny. Ontogenez 2008, 39, 367-373. [CrossRef] [PubMed]

(C) 2020 by the authors. Licensee MDPI, Basel, Switzerland. This article is an open access article distributed under the terms and conditions of the Creative Commons Attribution (CC BY) license (http://creativecommons.org/licenses/by/4.0/). 